\title{
Biomorphological Analysis of Forest Flora of Chechen Republic
}

\author{
Baybatyrova E.R. \\ Postgraduate student of the department of ecology \\ Chechen State Pedagogical University \\ Grozny, Russian Federation \\ elina-76-76@mail.ru
}

\begin{abstract}
The article is devoted to a comprehensive analysis of the structure of the forest flora of the Chechen Republic. Based on herbarium material and literary sources, 309 species of vascular plants belonging to 180 genera and 76 families have been studied. According to the groups of the biomorphological spectrum, the forest flora was rated as "hemicryptophytephanophyte". From the life forms in it trees and shrubs are dominated. Biomorphological analysis showed a fairly large variety of life forms, which indicates a variety of adaptive adaptations. The predominance of grassy life forms speaks of the grassy nature of the forest flora of the Chechen Republic. In the forest flora, 7 leading families are distinguished, including 113 species (which is $36.2 \%$ of the species composition of the flora). The composition of the leading families is typical of the floras of the Holarctic with signs of Boreal and Mediterranean flora.
\end{abstract}

Keywords - forest plant life, Chechen Republic, geographical analysis, life-forms, cenoflora

\section{INTRODUCTION}

The study of vegetation as a component of the geographical landscape is part of the implementation of the most important global problem - the study and preservation of biological diversity. One of the components of such research is a comprehensive study of cenoflora and their spatial distribution in a particular area, depending on many environmental factors - geography, topography, climate, nature of moisture, etc.

In this regard, the study of cenoflora, which exhibits pronounced azonation and is subject to the influence of the island effect, seems to be the most relevant, which, in turn, leads to disjunction of the ranges of certain species and ecological isolation of phytocenoses. One of these phytocenoses are forests. Isolated for a long time, they become refugiums of relict species, and, in some cases, speciation centers in which geographic races can isolate, and if the isolation is long enough on a geological time scale, then local endemics.

The originality of the forest flora is given by endemic and relict species, which are indicators of florogenetic changes occurring within a physical-geographical unit, in this case in the Chechen Republic. The analysis of data on this group of species allows one to obtain material for adjusting the model of phorogenesis within the study area and adjacent ones.
The isolation of forest phytocenoses in various types of landscape leads to the formation of heterogeneous floristic forest complexes, which allows florocenotic zoning of the territory and make adjustments to the existing botanical and geographical schemes.

The relevance of the study is also determined by the need to address the protection of certain types of forest plants and justify the allocation of specially protected natural reservations (SPNR).

\section{MethodS AND MATERIALS}

Comprehensive analysis was carried out on the basis of our own field research, herbarium material of other researchers, according to literature data. An annotated list of 309 species of vascular plants belonging to 180 genera from 76 families was compiled. The analysis of species by groups of the biomorphological spectrum was carried out according to the Raunkier system. The analysis of life forms was carried out according to the classification of I.G. Serebryakova. A geographical analysis of the forest flora of the Chechen Republic was also carried out.

\section{RESULTS}

Biological features of species are a very important feature in the analysis of flora. In the modern practice of floristic research, biological analysis is the calculation and subsequent review of the distribution of species in life forms. At the same time, the life form is understood as the reaction of a plant species to a complex of environmental factors in a long time, which forms the appearance of plants. It should be noted that plants that are not related and belong to different families and even classes take a similar life form under similar conditions.

The analysis of plant life forms is one of the components of the standard floristic analysis. To characterize this parameter in the classification of K. Raunkier [11], a whole series of works devoted to the study of the flora of various territories of the North Caucasus was used.

Life form, as an indicator of the adaptive capacity of the organism, provides an opportunity to analyze the relationship between the complex of ecological and biological environmental conditions and their adaptability to them.

The study of the life forms of forest flora species of the Chechen Republic according to K. Raunkier's system (Table 
1) revealed the prevalence of hemicryptophytes in its flora, uniting 177 species (57.3\% of the total number of urban flora). $12 \%$ of the total species composition of the flora is the share of cryptophytes (K) (37 species). Terophytes (T) constitute another dominant life form - 9.7\% (30 species). On the territory of the Chechen Republic under study, phanerophytes are represented by 57 species $(18.4 \%)$ and combine mesophanerophytes (Phms) - 7.1\% (22 species); microphanerophytes $(\mathrm{Phm}) \quad-\quad 4.2 \% \quad(13$ species $)$ and nanophanerophytes ( $\mathrm{Phn})-7.1 \%$ (22 species). A smaller part is accounted for by chamaephytes $(\mathrm{Ch})-2.6 \%$ (8 species).

Based on the analysis of the classification of species into groups of the biomorphological spectrum according to Raunkir, we concluded that the forest flora as a whole should be assessed as "hemicryptophyte-phanophyte".

TABLE I. BIOMORPHOLOGICAL SPECTRUM OF FOREST FLORA ACCORDING TO THE CLASSIFICATION OF RAUNKIER.

\begin{tabular}{|l|l|l|}
\hline \multicolumn{1}{|c|}{ Biomorphe } & $\begin{array}{c}\text { Absolute number } \\
\text { of species }\end{array}$ & $\begin{array}{c}\text { \% of the total } \\
\text { number of species }\end{array}$ \\
\hline Phanerophyte & 57 & 18,4 \\
\hline Mesophanerophyte & 22 & 7,1 \\
\hline Microphanerophyte & 13 & 4,2 \\
\hline Nanophanerophyte & 22 & 7,1 \\
\hline Chamaephyte & 8 & 2,6 \\
\hline Hemicryptophyte & 177 & 57,3 \\
\hline Cryptophyte & 37 & 12 \\
\hline Therophyte & 30 & 9,7 \\
\hline Total & 309 & 100,0 \\
\hline
\end{tabular}

For more detailed ecological characteristics, an analysis of the distribution of species by taxon is used, a much more fractional classification of life forms by I.G. Serebryakova. According to the classification I.G. Serebryakova biomorph spectrum of woody plants of the forest flora of the Chechen Republic (Table 2) is distributed as follows: trees - $10.7 \%$, shrubs $-9.1 \%$, half-shrubs $-1 \%$, lignifying lianas $-1.3 \%$. The largest number of species refers to trees - 33 species $(10.7 \%)$ and shrubs - 28 species (9.1\%).

Summing up the biomorphological analysis, we can state a fairly large variety of life forms, which indicates a variety of adaptive adaptations. The predominance of grassy life forms speaks of the grassy nature of the forest flora of the Chechen Republic.

We present the quantitative characteristics of the leading families in descending order: Asteraceae, Rosaceae, Poaceae, Apiaceae, Lamiaceae, Boraginaceae, Brassicaceae, they are expressed in table 3 .

The composition of the 7 leading families of flora, the territory under study consists of 113 species (which is $36.2 \%$ of the species composition of the flora), which, in turn, belong to 75 genera (which is $41.7 \%$ of the total number of genera).

The composition of the leading families is typical for the floras of the Holarctic, and the fixed order of their location in the spectrum indicates the presence in them of the characteristics characteristic of both the Boreal and the Mediterranean flora.
TABLE II. VITAL FORMS OF FOREST FLORA ACCORDING TO SEREBRYAKOV'S CLASSIFICATION

\begin{tabular}{|l|l|l|}
\hline \multicolumn{1}{|c|}{ Life-form } & Number of species & $\begin{array}{c}\text { \% of the total } \\
\text { number of } \\
\text { biomorphs }\end{array}$ \\
\hline Trees & 33 & $10,7 \%$ \\
\hline Shrubs & 28 & $9,1 \%$ \\
\hline Half-shrubs & 4 & $1,3 \%$ \\
\hline Wood type lianas & 4 & $1,3 \%$ \\
\hline Herb monocarpic & 17 & $5,5 \%$ \\
\hline $\begin{array}{l}\text { Monocarpic of long growing } \\
\text { season }\end{array}$ & 23 & $7,4 \%$ \\
\hline Sterzhnekornevoj polycarpic & 17 & $5,5 \%$ \\
\hline Rhizomatous polycarpic & 23 & $7,4 \%$ \\
\hline Gadding polycarpic & 28 & $9,1 \%$ \\
\hline Caespitose polycarpic & 11 & $3,5 \%$ \\
\hline Short root polycarpic & 59 & $19 \%$ \\
\hline Long root polycarpic & 17 & $5,5 \%$ \\
\hline Bulbous polycarpic & 13 & $4,2 \%$ \\
\hline Klubnekornevoj polycarpic & 13 & $4,2 \%$ \\
\hline Kistekornevoj polycarpic & 6 & $1,9 \%$ \\
\hline $\begin{array}{l}\text { Ryhlodernovannyj } \\
\text { polycarpic }\end{array}$ & 9 & $2,9 \%$ \\
\hline Total & 309 & 100 \\
\hline
\end{tabular}

TABLE III. SPECTRUM OF LARGE FAMILIES OF FOREST FLORA

\begin{tabular}{|l|l|l|l|l|}
\hline № & \multicolumn{1}{|c|}{ Family } & $\begin{array}{c}\text { Number of } \\
\text { genus }\end{array}$ & $\begin{array}{c}\text { Number of } \\
\text { species }\end{array}$ & $\begin{array}{c}\text { \% } \\
\text { participation } \\
\text { in flora }\end{array}$ \\
\hline 1 & Asteraceae & 15 & 28 & 9,0 \\
\hline 2 & Rosaceae & 14 & 22 & 7,1 \\
\hline 3 & Poaceae & 11 & 17 & 5,5 \\
\hline 4 & Apiaceae & 11 & 15 & 4,8 \\
\hline 5 & Lamiaceae & 10 & 11 & 3,5 \\
\hline 6 & Boraginaceae & 7 & 10 & 3,2 \\
\hline 7 & Brassicaceae & 7 & 10 & 3,2 \\
\hline \multicolumn{2}{|l|}{ Total: } & 75 & 113 & 36,3 \\
\hline
\end{tabular}

The boreal nature of the flora studied by us is particularly evident in the Asteraceae and Rosaceae families, but from West to East, there is a tendency to increase the influence of the role of Mediterranean flora. The third position is occupied by the family Poaceae, a large abundance of species which is observed in both the Arctic and Mediterranean flora, which, in turn, is a reflection of the continental conditions, on the one hand, and the likely anthropogenic extreme conditions, on the other, which pushes the family Apiaceae to the fourth position.

The Lamiaceae family is on the fifth place in the spectrum of the leading families in the forest flora of the Chechen Republic. The position of this family is also evidence of the presence of boreal features in the flora we study, but it is no less trivial for the Ancient Mediterranean.

The presence of a large abundance of species Boraginaceae and Brassicaceae (6th and 7th place) also reflects the characteristics of the ancient Mediterranean flora.

\section{CONCLUSION}

Thus, the analysis of the structure of the forest flora of the Chechen Republic have shown that groups of biomorphological spectrum of forest flora can be attributed to "hemicryptophyte-fanerovannoy". From life forms it is 
dominated by trees and shrubs. A wide variety of life forms indicates a variety of adaptive devices. In the forest flora there are 7 leading families, including 113 species (which is $36.2 \%$ of the species composition of the flora). The composition of the leading families is typical for the flora of the Holarctic with signs of Boreal and Mediterranean flora.

The work was carried out with the financial support of the intra-university grant of the Chechen State Pedagogical University for an initiative scientific research.

\section{References}

[1] "Areas of trees and shrubs of the USSR", vol. 1-3, 1977-1986, T. 1, Leningrad: Nauka, 1977, p 182; vol. 2, Leningrad: Nauka, 1980, p 144; vol. 3, Leningrad: Nauka, 1986, p. 182.

[2] M.M. Barkinhoev, "Natural and climatic resources of Ingushetia", Nalchik: Elf, 2002, p. 224.

[3] N.I. Volynkin, V.V. Dotsenko, "Landscapes and physiographic zoning of Chechen-Ingushetia", Problems of the physical geography of the North-Eastern Caucasus, Grozny: Chechen-Ingush book publishing house, 1979, pp. 132-171

[4] A.A. Golovlev, "Steppe hills, remnants of the Chechen plain as relict landscape formations", Reserve management and studies: Problems of protection and ecological restoration of steppe ecosystems, Orenburg, 2004, pp. 35-41.
[5] Zalikhanov M.Ch., Podrezov N.N., "On the issue of avalanche danger in the region of Chechen-Ingushetia", Trudy of the High Mountain Geophysical Institute, Issue 18, Snow and avalanches, Leningrad: Gidrometeoizdat, 1972, pp. 84-102.

[6] G.S. Leontyev, "Rain Shadows" beyond the Rocky Ridge of the Central Caucasus", News of the State Geographic Society, vol. 70, № 2, 1938 pp. 272-277.

[7] B.K. Lotiev, I.G. Sazonov, "To the geomorphological zoning of Chechen-Ingushetia", Problems of the physical geography of the NorthEastern Caucasus: Collection of scientific papers, Grozny, 1979, pp. 74 84.

[8] V.M. Motkin, E.F. Pavlov, A.M. Paykov, A.M. Papkova, "Soils of Chechnya", Vladikavkaz: Publication of the Land Administration of the Autonomous Region of Chechnya, 1930, p. 420.

[9] L.A. Nagumanova, S.A. Rezepova, "The role of neotectonic movements in the formation of the relief of the Nadterechnaya plain", Nature and economy of the Chechen-Ingush ASSR", Issue 5, Grozny, 1989, pp. 1216.

[10] N.V. Dumitrashko, "Natural conditions and natural resources of the USSR", Caucasus, Moscow: Nauka, 1966, p. 282.

[11] C. Raunkiaer, "Types biologiques pour la geographie botanique", Oversigt over det Kgl. «Danske Videnskabemes Selsk. Forhandl», 1903, № 5 .

[12] V.V. Ryzhikov, G.G. Samarskij, P.S. Anisimov, "The nature of the CIASSR", its protection and rational use, Grozny, Chechen-Ingush Book Publishing House, 1987, p. 96. 